УДК 378.1: 629.7

Дмитро Випорханюк, Житомирський військовий інститут імені С. П. Корольова, м. Житомир ORCID ID 0000-0003-0663-7013

Сергій Ковбасюк, доктор технічних наук, старший науковий співробітник Житомирський військовий інститут імені С. П. Корольова, м. Житомир

ORCID ID 0000-0002-6003-7660

Михайло Ракушев, доктор технічних наук, старший науковий співробітник Національний університет оборони України імені Івана Черняховського, м. Київ

ORCID ID 0000-0002-7703-3287

DOI: $10.33099 / 2617-1775 / 2019-02 / 33-45$

\title{
СТАН НОРМАТИВНОГО ЗАБЕЗПЕЧЕННЯ СИСТЕМИ ПІДГОТОВКИ ФАХІВЦІВ 3 ВИЩОЮ ОСВІТОЮ ЗА СПЕЦІАЛІЗАЦІЯМИ КОСМІЧНОЇ ДІЯЛЬНОСТІ У СФЕРІ ОБОРОНИ УКРАЇНИ
}

\begin{abstract}
Резюме. Розглянуто тенденції використання космічних технологій у сфері національної безпеки та оборони держави. За результатами аналізу стану нормативного забезпечення зроблено висновок про невідповідність існуючого переліку спеціалізацій підготовки фахівців з вищою освітою, щуо відносяться до космічної діяльності, сучасним потребам. Вироблені пропозииії з удосконалення нормативного забезпечення підготовки фахівців з метою підвищення основних спроможностей сил оборони держави та вирімення інших завдань начіональної безпеки і оборони.
\end{abstract}

Ключові слова: оборона держави; космічна діяльність; вища освіта.

Постановка проблеми. Завдання забезпечення обороноздатності України та сучасні загрози у сфері національної безпеки та оборони України вимагають прискореного розвитку космічних інформаційних технологій у державі та визначають нагальну потребу удосконалення організації застосування космічної техніки і використання результатів космічної діяльності у Збройних Силах (3С) України.

Закон України від 15 листопада 1996 року № 502/96-ВР “Про космічну діяльність” встановлює, що космічна діяльність у сфері оборони та національної безпеки здійснюється Міністерством оборони (МО) України разом 3 відповідними міністерствами та іншими центральними органами виконавчої влади, але їх компетенція, крім Державного космічного агентства України, законодавчо не визначена [1]. Нормативне врегулювання діяльності у зазначеній сфері в МО України та ЗС України лише розпочато. Зокрема, Положення про МО України визначає, що МО України “провадить відповідно до закону космічну діяльність у сфері оборони та національної безпеки України" [2]. Наказом МО України від 07.03.2019 року № 105 "Питання Міністерства оборони України" основним виконавцем функції МО України щодо “провадження, відповідно до закону, космічної діяльності у сфері оборони та національної безпеки України” визначене Управління 
інформаційних технологій МО України, а співвиконавцями - Департамент військово-технічної політики, розвитку озброєння та військової техніки МО України, військова частина А0515, Генеральний штаб (ГШ) ЗС України, Центральний науково-дослідний інститут озброєння та військової техніки ЗС України. Положення про ГШ ЗС України визначає, що Генеральний штаб відповідно до покладених на нього завдань "здійснює моніторинг та аналіз космічної обстановки в інтересах Збройних Сил, інших складових сил оборони для виконання завдань з оборони держави" [3]. Неврегульованими залишаються питання організаційного характеру, а саме: відсутні єдині концептуальні основи провадження космічної діяльності у МО України та ЗС України; низька взаємодія між структурними підрозділами МО України та ЗС України у провадженні космічної діяльності; не визначені пріоритети фінансування заходів провадження космічної діяльності; відсутні стандарти використання результатів космічної діяльності тощо.

Причинами виникнення такої ситуації, $\epsilon$ відсутність нормативно визначеної єдиної системи управління космічною діяльністю у сферах національної безпеки та оборони; відсутність державної космічної політики, військової космічної стратегії та космічної доктрини; низький рівень професійних космічних знань та усвідомлення ролі космічних спроможностей при проведенні наземних, повітряних і морських операцій; недостатні загальна обізнаність та знання 3 питань космічного інформаційного забезпечення, космічної підтримки операцій (бойових дій); нестача фахівців в області космосу, вузько спрямований характер їх професійної підготовки, дефіцит космічного досвіду у штабах всіх рівнів; відсутність єдиної воєнно-космічної науково-педагогічної школи.

У зв'язку з цим важливим напрямом удосконалення космічної діяльності у сфері оборони $є$ формування та розвиток системи підготовки і підвищення кваліфікації фахівців певних спеціальностей.

Аналіз останніх досліджень i публікацій. Формування системних підходів до організації космічної діяльності у сфері оборони України для забезпечення відбиття збройної агресії, формування основних (оперативних, бойових, спеціальних) спроможностей ЗС України (сил оборони) розглядається в роботах [4-8].

В роботі [4] розглянуті питання сучасного стану вітчизняної космічної галузі та використання космічних інформаційних технологій у секторі безпеки i оборони України, охарактеризовані заходи у сфері космічної діяльності МО України щодо розробки концептуальних документів 3 визначення пріоритетів розвитку та потреб ЗС України.

Питання удосконалення системи інформаційного забезпечення ЗС України в умовах проведення антитерористичної операції на сході України 3 урахуванням можливостей використання інформації космічних систем розглядаються в $[5,6]$.

На підставі аналізу світового досвіду космічної діяльності, сучасного стану та перспектив вітчизняної космічної діяльності, вимог нормативних документів 
у сфері оборони України в $[7,8]$ обгрунтовується доцільність впровадження нової моделі космічної діяльності відповідно до сучасних умов та національних інтересів шляхом формування інфраструктури космічного інформаційного забезпечення органів військового управління та космічної підтримки операцій (бойових дій) угруповань військ (сил) ЗС України (сил оборони) на основі розробки та запровадження стандартних процедур космічної підтримки (Space support) операцій (бойових дій) НАТО. Зокрема, в [7] зазначається, що збройна боротьба не втратила ролі інструмента сучасної зовнішньої політики, у чому Україна з 2014 року щодня переконується на власному досвіді протистояння російській агресії. Вагомим чинником російської агресії є іiї космічна складова, яку забезпечують потужна ракетно-космічна галузь та космічні війська РФ. Для забезпечення відбиття збройної агресії РФ, формування спроможностей ЗС України пропонується створення системи космічного інформаційного забезпечення (підтримки) сил оборони. Визначається, що основою підвищення ефективності виконання завдань оборони є спеціальна космічна інформація, космічні продукти та космічні послуги, які є результатом цілеспрямованої та скоординованої космічної діяльності, системного використання всієї наявної вітчизняної космічної інфраструктури в інтересах оборони держави. У [8], на підставі грунтовного опрацювання сучасного іноземного й вітчизняного досвіду космічної діяльності у сфері оборони, зазначається, що кардинальні зміни воєнно-політичної обстановки, обумовлені агресивними діями РФ 3 метою знищення держави Україна і захоплення іiі території, необхідність вирішення завдання відбиття російської агресії та відновлення територіальної цілісності України, загострили проблему невідповідності нинішнього стану космічної діяльності сучасним загрозам i завданням забезпечення обороноздатності держави, актуалізували необхідність суттєвого удосконалення ії системотворної ланки - космічної діяльності у сфері оборони. Пропонуються шляхи розв'язання проблеми невідповідності нинішнього стану космічної діяльності у сфері оборони України сучасним загрозам і завданням.

Однак питання підготовки фахівців 3 вищою освітою за спеціалізаціями космічної діяльності у сфері оборони у визначених публікаціях не розглядаються.

Мета статті. Метою статті є аналіз нормативного забезпечення системи підготовки фахівців з вищою освітою за спеціалізаціями космічної діяльності у сфері оборони України та вироблення пропозицій щодо удосконалення системи їх підготовки.

Виклад основного матеріалу. Світовий досвід космічної діяльності в інтересах оборони свідчить, що застосування космічної техніки дозволяє реалізувати якісно нові можливості використання потенціалу держави для стримування, а за необхідності й відсічі агресії противника.

Основними чинниками підвищення ефективності виконання завдань у сфері оборони шляхом застосування космічної техніки $є$ значне посилення основних спроможностей (оперативних, бойових, спеціальних) сил оборони щодо організації керівництва та управління (CONSULT, COMMAND \& 
CONTROL) різнорідними силами, забезпечення готовності військ (FORCE SUPPORT), розвідки (INFORM), розгортання та мобільності військ (PROJECT), їх застосування (ENGAGE), забезпечення (SUSTAIN), захисту та живучості (PROTECT) та, за необхідності, перешкоджання противникові використовувати аналогічні можливості космічної техніки.

Крім того, прогрес у створенні і застосуванні космічних та інформаційних технологій дозволяє на основі аналітичного оброблення даних про ситуацію в космічному просторі вирішувати такі завдання в інтересах національної безпеки і оборони: забезпечення безпеки польотів космічних апаратів (КА) та виявлення фактів інспекції і фізичного впливу на вітчизняні КА; визначення районів земної поверхні та часу можливого загострення ситуації; оповіщення про прольоти іноземних розвідувальних КА; організація протидії іноземним розвідувальним КА; планування використання національних КА та оцінка можливості використання даних іноземних КА; прогнозування районів можливого падіння небезпечних (аварійних, згоряючих) КО; пошук та встановлення зв'язку 3 КА, які виведені на нерозрахункову орбіту; використання даних моніторингу космічного простору в інтересах розвитку зовнішньоекономічної діяльності.

Для якісного вирішення цих завдань необхідні висококваліфіковані спеціалісти широкої номенклатури спеціалізацій. Акцент підготовки фахівців має бути зміщений з вивчення конкретних типів технологічного обладнання $\mathrm{i}$ типових алгоритмів оброблення даних, наприклад, даних дистанційного зондування Землі, в бік вивчення методологічних основ побудови i застосування орбітальних i наземних сегментів космічних систем, комплексного аналізу подій, оцінки ситуацій порівняно з їх попереднім станом, прогнозування розвитку обстановки.

Основні засади функціонування системи вищої освіти, забезпечення потреб держави у кваліфікованих фахівцях встановлює Закон України "Про вищу освіту" [9]. Згідно із Законом [9], перелік галузей знань і перелік спеціальностей, за якими здійснюється підготовка здобувачів вищої освіти, формує та подає на затвердження Кабінету Міністрів України центральний орган виконавчої влади у сфері освіти і науки.

Постановою Кабінету Міністрів України від 16.10.2014 р. № 630 затверджене Положення про Міністерство освіти i науки України (МОН України), згідно з яким МОН України є головним органом у системі центральних органів виконавчої влади, що забезпечує формування та реалізує державну політику у сферах освіти i науки, наукової, науково-технічної та інноваційної діяльності, трансферу (передачі) технологій, а також забезпечує формування та реалізацію державної політики у сфері здійснення державного нагляду (контролю) за діяльністю навчальних закладів [10].

Перелік галузей знань і спеціальностей, за якими здійснюється підготовка здобувачів вищої освіти, що затверджений постановою Кабінету Міністрів України від 29 квітня 2015 р. № 266 [11], прямо визначає лише одну, пов’язану 3 космічною діяльністю, спеціальність - “Авіаційна та ракетно-космічна 
техніка" (код спеціальності - 134) у галузі знань "Механічна інженерія" (шифр галузі - 13). Стосовно підготовки військових фахівців з вищою освітою у [11] визначена галузь знань "Воєнні науки, національна безпека, безпека державного кордону” та 6 відповідних їй спеціальностей (табл. 1).

Таблиця 1

Спеціальності галузі знань “Воєнні науки, національна безпека, безпека державного кордону"

\begin{tabular}{|c|c|c|c|}
\hline Шифр галузі & Галузь знань & $\begin{array}{c}\text { Код } \\
\text { спеціальності }\end{array}$ & Найменування спеціальності \\
\hline \multirow[t]{6}{*}{25} & \multirow{6}{*}{$\begin{array}{l}\text { Воєнні науки, } \\
\text { національна безпека, } \\
\text { безпека державного } \\
\text { кордону }\end{array}$} & 251 & Державна безпека \\
\hline & & 252 & Безпека державного кордону \\
\hline & & 253 & $\begin{array}{l}\text { Військове управління } \\
\text { (за видами збройних сил) }\end{array}$ \\
\hline & & 254 & Забезпечення військ (сил) \\
\hline & & 255 & Озброєння та військова техніка \\
\hline & & 256 & Національна безпека \\
\hline
\end{tabular}

Приведення спеціальностей i спеціалізацій, за якими раніше здійснювалася підготовка фахівців з вищою освітою, у відповідність чинному Переліку галузей знань і спеціальностей [11] здійснюється згідно з наказом МОН України від 06.11.2015 року № 1151 "Про особливості запровадження переліку галузей знань і спеціальностей, за якими здійснюється підготовка здобувачів вищої освіти, затвердженого постановою Кабінету Міністрів України від 29.04.2015 року № 266” [12].

Зазначеним наказом затверджена Таблиця відповідності Переліку напрямів, за якими здійснювалася підготовка фахівців у вищих навчальних закладах за освітньо-кваліфікаційним рівнем бакалавра (Перелік 1), Переліку спеціальностей, за якими здійснювалася підготовка фахівців у вищих навчальних закладах за освітньо-кваліфікаційними рівнями спеціаліста i магістра (Перелік 2), та Переліку галузей знань і спеціальностей, за якими здійснюється підготовка здобувачів вищої освіти, затвердженого постановою Кабінету Міністрів України від 29 квітня 2015 року № 266 (Перелік 2015) (далі - Таблиця відповідності).

Але, якщо у розділі "Військові науки" Таблиці відповідності [12] стосовно напрямів і спеціальностей у сфері державної безпеки зазначається "Напрями (спеціальності), визначені нормативно-правовими актами Служби безпеки України за погодженням з Міністерством освіти і науки України", то щодо спеціальностей "253 - Військове управління (за видами збройних сил)", "254 - Забезпечення військ (сил)", "255 - Озброєння та військова техніка" дані відсутні.

Переліки спеціалізацій підготовки військових фахівців 3 вищою освітою були визначені наказом МО України від 24.12.2015 року № 752 [13], яким стосовно підготовки військових фахівців з вищою освітою за спеціалізаціями, що безпосередньо відносяться до космічної діяльності визначені лише три 
спеціалізації у двох галузях знань: експлуатація військових засобів радіо- та супутникового зв'язку; обробка даних космічної розвідки; організація військово-космічних систем (табл. 2).

Таблиця 2

Галузі знань, спеціальності та спеціалізації підготовки військових фахівців 3 вищою освітою, що безпосередньо відносяться до космічної діяльності за наказом МО України від 24.12.2015 № 752

\begin{tabular}{|c|c|c|c|}
\hline $\begin{array}{l}\text { № } \\
\text { 3/ח }\end{array}$ & $\begin{array}{l}\text { Шифр та найменування галузі } \\
\text { знань }\end{array}$ & $\begin{array}{c}\text { Код та найменування } \\
\text { спеціальності }\end{array}$ & $\begin{array}{r}\text { Наймен } \\
\text { спеціа }\end{array}$ \\
\hline \multicolumn{4}{|c|}{$\begin{array}{c}\text { Перелік спеціалізацій підготовки військових фахівців за ступенем вищої освіти молодшого } \\
\text { бакалавра }\end{array}$} \\
\hline 7 & $\begin{array}{l}17 \\
\text { телекомунікації }\end{array}$ & $\begin{array}{r}172 \text { Телекс } \\
\text { та радіо }\end{array}$ & $\begin{array}{l}\text { Експлуатація військових засобів } \\
\text { радіо- та супутникового зв'язку }\end{array}$ \\
\hline \multicolumn{4}{|c|}{$\begin{array}{c}\text { Перелік спеціалізацій підготовки військових фахівців за ступенями вищої освіти бакалавра } \\
\text { та магістра }\end{array}$} \\
\hline \multicolumn{4}{|c|}{ Тактичний рівень підготовки } \\
\hline 17 & $\begin{array}{l}25 \text { Воєнні науки, національна } \\
\text { безпека, безпека державного } \\
\text { кордону }\end{array}$ & $\begin{array}{l}2550 \\
\text { військ }\end{array}$ & $\begin{array}{r}\text { Обр } \\
\text { космі }\end{array}$ \\
\hline \multicolumn{4}{|c|}{$\begin{array}{l}\text { Перелік спеціалізацій підготовки військових фахівців оперативно-тактичного рівня } \\
\text { військової освіти }\end{array}$} \\
\hline 2 & $\begin{array}{l}25 \text { Воєнні науки, національна } \\
\text { безпека, безпека державного } \\
\text { кордону }\end{array}$ & $\begin{array}{l}254 \text { Забезпечення } \\
\text { військ (сил) }\end{array}$ & $\begin{array}{c}\text { Організація } \\
\text { військово-космічних систем }\end{array}$ \\
\hline
\end{tabular}

Наказ МО України від 25.04.2016 року № 216 “Про вдосконалення підготовки офіцерських кадрів тактичного рівня та сержантського (старшинського) складу у вищих військових навчальних закладах та військових навчальних підрозділах вищих навчальних закладів" [14] визначив завдання: “4. Курсантів, прийнятих на навчання у 2013, 2014, 2015 роках, перевести у 2016-2017 навчальному році на навчання за спеціальностями та спеціалізаціями, що визначені наказом ГШ ЗС України від 26 березня 2016 року № 122 "Про затвердження Переліку спеціалізацій, за якими визначаються потреби на підготовку військових фахівців 3 вищою освітою, Додаткового переліку спеціалізацій, за якими визначаються потреби на підготовку військових фахівців з вищою освітою у 2016 році, та Переліку військовооблікових спеціальностей осіб офіцерського складу, що відповідають спеціальностям та спеціалізаціям підготовки військових фахівців” та визначеними цим наказом строками навчання за відповідними ступенями вищої освіти".

Наказом ГШ ЗС України від 26.03.2016 р. № 122 [15] визначена лише одна спеціалізація підготовки військових фахівців 3 вищою освітою, що безпосередньо відносяться до космічної діяльності - обробка даних космічної розвідки за спеціальністю "255 Озброєння та військова техніка" у галузі знань "Воєнні науки, національна безпека, безпека державного кордону". 
Разом 3 тим, до 2015 року нормативними документами визначалася послідовна та взаємопов'язана система підготовки військових фахівців 3 вищою освітою у сфері космічної діяльності. А саме:

постанова Кабінету Міністрів України від 27.08.2010 р. № 787 "Про затвердження переліку спеціальностей, за якими здійснюється підготовка фахівців у вищих навчальних закладах за освітньо-кваліфікаційними рівнями спеціаліста і магістра" [16] передбачала, що для галузі знань "1601 Військові науки, національна безпека, безпека державного кордону” перелік галузей знань, напрямів і спеціальностей підготовки військових фахівців визначався відповідними центральними органами виконавчої влади за погодженням із МОН України;

наказ МО України від 19.06.2012 р. № 408 “Про затвердження переліків спеціальностей та спеціалізацій, за якими здійснюється підготовка військових фахівців у вищих військових навчальних закладах та військових навчальних підрозділах вищих навчальних закладів за відповідними освітньокваліфікаційними рівнями" [17] визначав переліки спеціальностей та спеціалізацій, за якими здійснювалася підготовка військових фахівців, що відносяться до космічної діяльності (табл. 3).

Таблиця 3

Галузі знань, напрями, спеціальності та спеціалізації підготовки військових фахівців, що відносяться до космічної діяльності, згідно із наказом МО України від 19.06.2012 р. № 408

Освітньо-кваліфікаційний рівень бакалавра

\begin{tabular}{|c|c|c|c|c|}
\hline $\begin{array}{l}\text { № } \\
3 / \\
\Pi\end{array}$ & $\begin{array}{c}\text { Шифр та } \\
\text { найменування } \\
\text { галузі знань }\end{array}$ & \begin{tabular}{|c} 
Код i \\
напрям \\
підготовки
\end{tabular} & $\begin{array}{c}\text { Спеціальність } \\
\text { підготовки }\end{array}$ & $\begin{array}{c}\text { Спеціалізація та спеціальності } \\
\text { підготовки }\end{array}$ \\
\hline 12 & $\begin{array}{l}0502 . \\
\text { Автоматика та } \\
\text { управління }\end{array}$ & $\begin{array}{l}6.050201 . \\
\text { Системна } \\
\text { інженерія }\end{array}$ & $\begin{array}{l}\text { Комплекси, системи та } \\
\text { засоби автоматизації } \\
\text { управління військами і } \\
\text { озброєнням }\end{array}$ & Обробка даних к \\
\hline 16 & $\begin{array}{l}0509 . \\
\text { Радіотехніка, } \\
\text { радіоелектронні } \\
\text { апарати та } \\
\text { зв’язок }\end{array}$ & $\begin{array}{l}6.050901 . \\
\text { Радіотехні } \\
\text { ка }\end{array}$ & $\begin{array}{l}\text { Радіоелектронні } \\
\text { комплекси та системи } \\
\text { озброєння і військової } \\
\text { техніки спеціального } \\
\text { призначення }\end{array}$ & $\begin{array}{l}\text { Радіоелектронні системи бортових та } \\
\text { наземних засобів космічних } \\
\text { комплексів. } \\
\text { Засоби спеціального контролю. } \\
\text { Радіоелектронні засоби надобрійного } \\
\text { виявлення та контролю космічного } \\
\text { простору. }\end{array}$ \\
\hline \multicolumn{5}{|c|}{ Освітньо-кваліфікаційні рівні спеціаліста і магістра } \\
\hline $\begin{array}{l}\text { № } \\
3 / \\
\Pi\end{array}$ & $\begin{array}{c}\text { Шифр та } \\
\text { найменування } \\
\text { галузі знань }\end{array}$ & \multicolumn{2}{|c|}{$\begin{array}{c}\text { Освітньо-кваліфікаційний рівень } \\
\text { спеціаліста (код і найменування } \\
\text { спеціальності, спеціалізації) }\end{array}$} & $\begin{array}{c}\text { Освітньо-кваліфікаційний рівень } \\
\text { магістра } \\
\text { (код і найменування спеціальності, } \\
\text { спеціалізації) }\end{array}$ \\
\hline & $\begin{array}{l}0502 . \\
\text { Автоматика та } \\
\text { управління }\end{array}$ & \multicolumn{2}{|c|}{$\begin{array}{l}\text { 7.05020181. Комплекси, системи та } \\
\text { засоби автоматизації управління } \\
\text { військами і озброєнням. }\end{array}$} & $\begin{array}{l}\text { 8.05020181. Комплекси, системи та } \\
\text { засоби автоматизації управління } \\
\text { військами і озброєнням. }\end{array}$ \\
\hline
\end{tabular}




\begin{tabular}{|c|c|c|}
\hline & $\begin{array}{l}\text { Спеціалізації: обробка даних } \\
\text { космічної розвідки }\end{array}$ & $\begin{array}{l}\text { Спеціалізації: обробка даних } \\
\text { космічної розвідки }\end{array}$ \\
\hline $17 \begin{array}{l}0509 . \\
\text { Радіотехніка, } \\
\text { радіоелектронні } \\
\text { апарати та } \\
\text { зв'язок }\end{array}$ & $\begin{array}{l}\text { 7.05090183. Радіоелектронні } \\
\text { комплекси та системи озброєння і } \\
\text { військової техніки спеціального } \\
\text { призначення. } \\
\text { Спеціалізації: } \\
\text { радіоелектронні системи бортових } \\
\text { та наземних засобів космічних } \\
\text { комплексів; } \\
\text { засоби спеціального контролю; } \\
\text { радіоелектронні засоби } \\
\text { надобрійного виявлення та } \\
\text { контролю космічного простору }\end{array}$ & $\begin{array}{l}\text { 8.05090183. Радіоелектронні } \\
\text { комплекси та системи озброєння і } \\
\text { військової техніки спеціального } \\
\text { призначення. } \\
\text { Спеціалізації: } \\
\text { радіоелектронні системи бортових та } \\
\text { наземних засобів космічних } \\
\text { комплексів; } \\
\text { засоби спеціального контролю; } \\
\text { радіоелектронні засоби надобрійного } \\
\text { виявлення та контролю космічного } \\
\text { простору. }\end{array}$ \\
\hline
\end{tabular}

3 урахуванням викладеного вище, доцільним $є$ доповнення Переліку спеціалізацій підготовки військових фахівців базовими спеціалізаціями у сфері космічної діяльності:

наземні засоби моніторингу космічної обстановки;

радіоелектронні системи бортових та наземних засобів космічних комплексів;

засоби спеціального контролю.

У цьому разі підготовка військових фахівців 3 вищою освітою за базовими спеціалізаціями космічної діяльності буде побудована за логічною, послідовною та взаємопов'язаною структурою на різних освітньокваліфікаційних рівнях, а спеціалізація підготовки військових фахівців оперативно-тактичного рівня військової освіти “Організація військовокосмічних систем” набуде відповідної системності та повноти (табл. 4):

Таблиця 4

Пропозиції щодо спеціалізацій підготовки військових фахівців 3 вищою освітою, що прямо відносяться до космічної діяльності

\begin{tabular}{|c|c|c|c|}
\hline $\begin{array}{l}\text { № } \\
\text { 3/П }\end{array}$ & $\begin{array}{c}\text { Шифр та найменування } \\
\text { галузі знань }\end{array}$ & $\begin{array}{c}\text { Код та найменування } \\
\text { спеціальності }\end{array}$ & $\begin{array}{l}\text { Найменування } \\
\text { спеціалізації }\end{array}$ \\
\hline \multicolumn{4}{|c|}{$\begin{array}{c}\text { Перелік спеціалізацій підготовки військових фахівців за ступенями вищої освіти бакалавра } \\
\text { та магістра }\end{array}$} \\
\hline \multicolumn{4}{|c|}{ Тактичний рівень підготовки } \\
\hline & $\begin{array}{l}25 \text { Воєнні науки, національна } \\
\text { безпека, безпека державного } \\
\text { кордону }\end{array}$ & $\begin{array}{l}255 \text { Озброєння та } \\
\text { військова техніка }\end{array}$ & $\begin{array}{l}\text { Наземні засоби моніторингу } \\
\text { космічної обстановки; } \\
\text { радіоелектронні системи бортових та } \\
\text { наземних засобів космічних } \\
\text { комплексів; } \\
\text { обробка даних космічної розвідки; } \\
\text { засоби спеціального контролю }\end{array}$ \\
\hline
\end{tabular}


Перелік спеціалізацій підготовки військових фахівців оперативно-тактичного рівня військової освіти

225 Воєнні науки, національна 254 Забезпечення Організація військово-космічних безпека, безпека державного військ (сил) систем кордону

на тактичному рівні за ступенями вищої освіти бакалавра та магістра підготовку - за спеціалізаціями наземні засоби моніторингу космічної обстановки, радіоелектронні системи бортових та наземних засобів космічних комплексів, обробка даних космічної розвідки, засоби спеціального контролю;

на оперативно-тактичному рівні військової освіти - за спеціалізацією “організація військово-космічних систем”.

Висновки. Використання сучасних космічних інформаційних технологій необхідне для підвищення основних спроможностей сил оборони та вирішення інших завдань безпеки держави, що потребує підготовки фахівців широкої номенклатури спеціалізацій 3 акцентом на знаннями методологічних основ побудови i застосування космічних систем орбітального та наземного базування, аналітичного i комплексного аналізу подій, ретроспективної i перспективної оцінки ситуації.

Результати аналізу нормативного забезпечення системи підготовки фахівців 3 вищою освітою за спеціалізаціями космічної діяльності у сфері оборони України показали фактичне зменшення їх переліку i звуження напрямів підготовки.

3 метою забезпечення ефективного вирішення завдань оборони держави, формування та підтримання основних спроможностей ЗС України та інших складових сил оборони шляхом створення системи космічного інформаційного забезпечення в МО України і ЗС України запропоновано доповнити Перелік спеціалізацій підготовки військових фахівців базовими спеціалізаціями у сфері космічної діяльності. До переліку спеціалізацій тактичного рівня доцільно включити: наземні засоби моніторингу космічної обстановки, радіоелектронні системи бортових та наземних засобів космічних комплексів, обробка даних космічної розвідки, засоби спеціального контролю, а до переліку спеціалізацій оперативно-тактичного рівня військової освіти - організацію військовокосмічних систем.

Напрями подальших досліджень. Подальші дослідження будуть спрямовані на організаційно-методичне забезпечення підготовки військових фахівців для системи космічного інформаційного забезпечення, яка призначена для добування, збору, оброблення та доведення інформації про свої війська, зброю та противника в інтересах максимально ефективного застосування військ (сил) на основі використання сучасних космічних технологій та засобів.

\section{ЛІТЕРАТУРА}

1. Закон України “Про космічну діяльність” від 15.11.1996 року № 502/96-ВР (із змінами) // [Електронний ресурс]. - Режим доступу: http://zakon.rada.gov.ua. 
2. Положення про Міністерство оборони України. Затверджено постановою Кабінету Міністрів України від 26 листопада 2014 р. № 671 (у редакції постанови Кабінету Міністрів України від 19 жовтня 2016 р. № 730) (із змінами) // [Електронний ресурс]. Режим доступу: https://zakon.rada.gov.ua/laws/show/671-2014.

3. Указ Президента України "Про Положення про Генеральний штаб Збройних Сил України” від 30 січня 2019 року № 23/2019// [Електронний ресурс]. Режим доступу: https://zakon.rada.gov.ua/laws/show/23/2019.

4. Соколов К.О. Питання космічної діяльності в секторі безпеки і оборони / К.О. Соколов, О.П. Гудима, О.Б. Шиятий // Тринадцята наукова конференція ХНУПС імені Івана Кожедуба "Новітні технології - для захисту повітряного простору”: тези доповідей, 1213 квітня 2017 року. - Х.: ХНУПС ім. І. Кожедуба. - 2017. - С. 453.

5. Гудима О.П. Проблеми використання інформації космічних систем та удосконалення геоінформаційного забезпечення при виконанні завдань АТО / О.П. Гудима, Г.В. Пєвцов, М.Ф. Пічугін // Тринадцята наукова конференція ХНУПС імені Івана Кожедуба "Новітні технології - для захисту повітряного простору”: тези доповідей, 12-13 квітня 2017 року. - Х.: ХНУПС ім. І. Кожедуба. - 2017. - С. 452.

6. Гудима О.П. Рекомендації щодо підвищення ефективності використання та удосконалення існуючої наземної інфраструктури управління і отримання інформації 3 вітчизняних космічних апаратів / О.П. Гудима, Г.В. Пєвцов, Д.В. Карлов, О.І. Солонець, Ю.В. Рєзніков // Тринадцята наукова конференція ХНУПС імені Івана Кожедуба "Новітні технології - для захисту повітряного простору": тези доповідей, 12-13 квітня 2017 року. - Х.: ХНУПС ім. І. Кожедуба. - 2017. - С. 455.

7. Випорханюк Д.М. Методологічні засади здійснення космічної діяльності у сфері оборони / Д.М. Випорханюк, С.В. Ковбасюк // Науково-практична конференція НЦУВКЗ “Аерокосмічні технології в Україні: проблеми та перспективи”: тези доповідей, 4 жовтня 2017 року. - К.: НЦУВКЗ. - 2017. - С. 61-62.

8. Випорханюк Д.М., Ковбасюк С.В. Основи космічної ситуаційної обізнаності (Space Situational Awareness, SSA). Іноземний і вітчизняний досвід космічної діяльності у сфері оборони : Монографія. Житомир : Вид. О.О. Свенок, 2018. 532 с.

9. Закон України "Про вищу освіту" від 1.07.2014 року № 1556-VII (із змінами) // [Електронний ресурс]. - Режим доступу: http://zakon.rada.gov.ua.

10. Постанова Кабінету Міністрів України від 16.10.2014 року № 630 "Про затвердження Положення про Міністерство освіти і науки України" // [Електронний peсурс]. - Режим доступу: http://zakon.rada.gov.ua.

11. Постанова Кабінету Міністрів України "Про затвердження переліку галузей знань і спеціальностей, за якими здійснюється підготовка здобувачів вищої освіти" від 29 квітня 2015 р. № 266 (Із змінами, внесеними Постановами КМУ № 674 від 27.09.2016, № 53 від 01.02.2017) // [Електронний ресурс]. - Режим доступу: http://zakon.rada.gov.ua.

12. Наказ Міністерства освіти і науки України від 06.11.2015 року № 1151 “Про особливості запровадження переліку галузей знань і спеціальностей, за якими здійснюється підготовка здобувачів вищої освіти, затвердженого постановою Кабінету Міністрів України від 29 квітня 2015 року № 266” // [Електронний ресурс]. - Режим доступу: // http://old.mon.gov.ua/ua/about-ministry/normative/4636.

13. Наказ Міністерства оборони України від 24.12.2015 року № 752 “Про затвердження переліків спеціалізацій підготовки військових фахівців з вищою освітою” // [Електронний ресурс]. - Режим доступу: http://www.mil.gov.ua.

14. Наказ Міністерства оборони України від 25.04.2016 року № 216 "Про вдосконалення підготовки офіцерських кадрів тактичного рівня та сержантського (старшинського) складу у вищих військових навчальних закладах та військових навчальних підрозділах вищих навчальних закладів" // [Електронний ресурс]. - Режим доступу: http://www.mil.gov.ua. 
15. Наказ Генерального штабу Збройних Сил України від 26.03.2016 року № 122 “Про затвердження Переліку спеціалізацій, за якими визначаються потреби на підготовку військових фахівців з вищою освітою, Додаткового переліку спеціалізацій, за якими визначаються потреби на підготовку військових фахівців з вищою освітою у 2016 році, та Переліку військово-облікових спеціальностей осіб офіцерського складу, що відповідають спеціальностям та спеціалізаціям підготовки військових фахівців" // [Електронний ресурс]. Режим доступу: http://www.mil.gov.ua.

16. Постанова Кабінету Міністрів України “Про затвердження переліку спеціальностей, за якими здійснюється підготовка фахівців у вищих навчальних закладах за освітньо-кваліфікаційними рівнями спеціаліста і магістра” від 27 серпня 2010 р. № 787 // [Електронний ресурс]. - Режим доступу: http://zakon.rada.gov.ua.

17. Наказ Міністерства оборони України від 19.06.2012 року № 408 "Про затвердження переліків спеціальностей та спеціалізацій, за якими здійснюється підготовка військових фахівців у вищих військових навчальних закладах та військових навчальних підрозділах вищих навчальних закладів за відповідними освітньо-кваліфікаційними рівнями" // [Електронний ресурс]. - Режим доступу: http://www.mil.gov.ua.

\section{REFERENCES}

1. Zakon Ukrainy "Pro kosmichnu diialnist" vid 15.11.1996 roku № 502/96-VR (iz zminamy) // [Elektronnyi resurs]. - Rezhym dostupu: http://zakon.rada.gov.ua.

2. Polozhennia pro Ministerstvo oborony Ukrainy. Zatverdzheno postanovoiu Kabinetu Ministriv Ukrainy vid 26 lystopada 2014 r. № 671 (u redaktsii postanovy Kabinetu Ministriv Ukrainy vid 19 zhovtnia 2016 r. № 730) (iz zminamy) // [Elektronnyi resurs]. Rezhym dostupu: https://zakon.rada.gov.ua/laws/show/671-2014.

3. Ukaz Prezydenta Ukrainy "Pro Polozhennia pro Heneralnyi shtab Zbroinykh Syl Ukrainy” vid 30 sichnia 2019 roku № 23/2019// [Elektronnyi resurs]. Rezhym dostupu: https://zakon.rada.gov.ua/laws/show/23/2019.

4. Sokolov K.O. Pytannia kosmichnoi diialnosti v sektori bezpeky i oborony / K.O. Sokolov, O.P. Hudyma, O.B. Shyiatyi // Trynadtsiata naukova konferentsiia KhNUPS imeni Ivana Kozheduba "Novitni tekhnolohii - dlia zakhystu povitrianoho prostoru": tezy dopovidei, 12-13 kvitnia 2017 roku. - X.: KhNUPS im. I. Kozheduba. - 2017. - S. 453.

5. Hudyma O.P. Problemy vykorystannia informatsii kosmichnykh system ta udoskonalennia heoinformatsiinoho zabezpechennia pry vykonanni zavdan ATO / O.P. Hudyma, H.V. Pievtsov, M.F. Pichuhin // Trynadtsiata naukova konferentsiia KhNUPS imeni Ivana Kozheduba "Novitni tekhnolohii - dlia zakhystu povitrianoho prostoru": tezy dopovidei, 12-13 kvitnia 2017 roku. - X.: KhNUPS im. I. Kozheduba. - 2017. - S. 452.

6. Hudyma O.P. Rekomendatsii shchodo pidvyshchennia efektyvnosti vykorystannia ta udoskonalennia isnuiuchoi nazemnoi infrastruktury upravlinnia i otrymannia informatsii $z$ vitchyznianykh kosmichnykh aparativ / O.P. Hudyma, H.V. Pievtsov, D.V. Karlov, O.I. Solonets, Yu.V. Rieznikov // Trynadtsiata naukova konferentsiia KhNUPS imeni Ivana Kozheduba "Novitni tekhnolohii - dlia zakhystu povitrianoho prostoru": tezy dopovidei, 12-13 kvitnia 2017 roku. - X.: KhNUPS im. I. Kozheduba. - 2017. - S. 455.

7. Vyporkhaniuk D.M. Metodolohichni zasady zdiisnennia kosmichnoi diialnosti u sferi oborony / D.M. Vyporkhaniuk, S.V. Kovbasiuk // Naukovo-praktychna konferentsiia NTsUVKZ "Aerokosmichni tekhnolohii v Ukraini: problemy ta perspektyvy": tezy dopovidei, 4 zhovtnia 2017 roku. - K.: NTsUVKZ. - 2017. - S. 61-62.

8. Vyporkhaniuk D.M., Kovbasiuk S.V. Osnovy kosmichnoi sytuatsiinoi obiznanosti (Space Situational Awareness, SSA). Inozemnyi i vitchyznianyi dosvid kosmichnoi diialnosti u sferi oborony : Monohrafiia. Zhytomyr : Vyd. O.O. Yevenok, 2018. $532 \mathrm{~s}$.

9. Zakon Ukrainy "Pro vyshchu osvitu” vid 1.07.2014 roku № 1556-VII (iz zminamy) // [Elektronnyi resurs]. - Rezhym dostupu: http://zakon.rada.gov.ua. 
10. Postanova Kabinetu Ministriv Ukrainy vid 16.10.2014 roku № 630 "Pro zatverdzhennia Polozhennia pro Ministerstvo osvity i nauky Ukrainy" // [Elektronnyi resurs]. - Rezhym dostupu: http://zakon.rada.gov.ua.

11. Postanova Kabinetu Ministriv Ukrainy "Pro zatverdzhennia pereliku haluzei znan i spetsialnostei, za yakymy zdiisniuietsia pidhotovka zdobuvachiv vyshchoi osvity" vid 29 kvitnia 2015 r. № 266 (Iz zminamy, vnesenymy Postanovamy KMU № 674 vid 27.09.2016, № 53 vid 01.02.2017) // [Elektronnyi resurs]. - Rezhym dostupu: http://zakon.rada.gov.ua.

12. Nakaz Ministerstva osvity i nauky Ukrainy vid 06.11.2015 roku № 1151 "Pro osoblyvosti zaprovadzhennia pereliku haluzei znan i spetsialnostei, za yakymy zdiisniuietsia pidhotovka zdobuvachiv vyshchoi osvity, zatverdzhenoho postanovoiu Kabinetu Ministriv Ukrainy vid 29 kvitnia 2015 roku № 266" // [Elektronnyi resurs]. - Rezhym dostupu: // http://old.mon.gov.ua/ua/about-ministry/normative/4636.

13. Nakaz Ministerstva oborony Ukrainy vid 24.12.2015 roku № 752 "Pro zatverdzhennia perelikiv spetsializatsii pidhotovky viiskovykh fakhivtsiv z vyshchoiu osvitoiu" // [Elektronnyi resurs]. - Rezhym dostupu: http://www.mil.gov.ua.

14. Nakaz Ministerstva oborony Ukrainy vid 25.04.2016 roku № 216 "Pro vdoskonalennia pidhotovky ofitserskykh kadriv taktychnoho rivnia ta serzhantskoho (starshynskoho) skladu u vyshchykh viiskovykh navchalnykh zakladakh ta viiskovykh navchalnykh pidrozdilakh vyshchykh navchalnykh zakladiv" // [Elektronnyi resurs]. - Rezhym dostupu: http://www.mil.gov.ua.

15. Nakaz Heneralnoho shtabu Zbroinykh Syl Ukrainy vid 26.03.2016 roku № 122 "Pro zatverdzhennia Pereliku spetsializatsii, za yakymy vyznachaiutsia potreby na pidhotovku viiskovykh fakhivtsiv z vyshchoiu osvitoiu, Dodatkovoho pereliku spetsializatsii, za yakymy vyznachaiutsia potreby na pidhotovku viiskovykh fakhivtsiv z vyshchoiu osvitoiu u 2016 rotsi, ta Pereliku viiskovo-oblikovykh spetsialnostei osib ofitserskoho skladu, shcho vidpovidaiut spetsialnostiam ta spetsializatsiiam pidhotovky viiskovykh fakhivtsiv" // [Elektronnyi resurs]. Rezhym dostupu: http://www.mil.gov.ua.

16. Postanova Kabinetu Ministriv Ukrainy "Pro zatverdzhennia pereliku spetsialnostei, za yakymy zdiisniuietsia pidhotovka fakhivtsiv u vyshchykh navchalnykh zakladakh za osvitnokvalifikatsiinymy rivniamy spetsialista i mahistra” vid 27 serpnia 2010 r. № 787 // [Elektronnyi resurs]. - Rezhym dostupu: http://zakon.rada.gov.ua.

17. Nakaz Ministerstva oborony Ukrainy vid 19.06.2012 roku № 408 “Pro zatverdzhennia perelikiv spetsialnostei ta spetsializatsii, za yakymy zdiisniuietsia pidhotovka viiskovykh fakhivtsiv $\mathrm{u}$ vyshchykh viiskovykh navchalnykh zakladakh ta viiskovykh navchalnykh pidrozdilakh vyshchykh navchalnykh zakladiv za vidpovidnymy osvitno-kvalifikatsiinymy rivniamy" // [Elektronnyi resurs]. - Rezhym dostupu: http://www.mil.gov.ua.

\section{PЕЗЮМЕ}

Дмитрий Выпорханюк,

Житомирский военный институт имени С. П. Королева, г. Житомир

Сергей Ковбасюк, доктор технических наук, старший научный сотрудник.

Житомирский военный институт имени С. П. Королева, г. Житомир

Михаил Ракушев доктор технических наук, старший научный сотрудник. Национальный университет обороны Украины имени Ивана Черняховского, Киев

\section{Состояние нормативного обеспечения системы подготовки специалистов с высшим образованием по специализациям космической деятельности в сфере обороны Украины}


Рассмотрень тенденции использования космических технологий в области национальной безопасности и обороны государства. По результатам анализа состояния нормативного обеспечения сделан вывод о несоответствии существующего перечня специализаций подготовки специиалистов с высшим образованием, которые относятся к космической деятельности, современным требованиям. Разработаны предложения по усовершенствованию нормативного обеспечения подготовки специалистов с целью повышения основных возможностей сил обороны страны и решения других задач национальной безопасности и оборонь.

Ключевые слова: оборона государства; космическая деятельность; высшее образование.

\title{
SUMMARY
}

\author{
Dmitry Vyporkhaniuk, \\ Zhitomir military institute \\ named after S. P. Koroljv, c. Zhitomir \\ Sergey Kovbasiuk, \\ Doctor of Sciences (Technical), Senior Scientific Researcher, \\ Zhitomir military institute \\ named after S. P. Koroljv, c. Zhitomir \\ Michael Rakushev, \\ Doctor of Sciences (Technical), Senior Scientific Researcher \\ National Defence University of Ukraine \\ named after Ivan Cherniakhovskyi, c. Kyiv
}

The status of normative ensuring system of training specialists with higher education for the professions of space activities in the sphere of defence of Ukraine

Trends in the use of space technologies in the field of national security and defense of the state are considered. Based on the analysis of the state of regulatory provision, it was concluded that the existing list of specializations of training specialists with higher education, which relate to space activities, modern requirements, is inconsistent. Proposals have been developed to improve the regulatory provision of training in order to improve the basic capabilities of the country's defence forces and other national security and defence tasks.

Key words: state defense; space activities; higher education. 